\title{
Small Business Financing - an Economic Growth Stimulator
}

\author{
Lilia IVAS, Alecu Russo Balti State University Republic Of Moldova
}

\begin{abstract}
Small business is an important lever for solving a whole complex of political, economic and social problems, taking into consideration its effectiveness in society. It attracts population to promote economic reforms, it fulfils the market with goods and services, it creats new job places, it grows entrepreneurial spirit and entrepreneurial culture, developes a careful attitude towards property, forms a progressive structure of the national economy. We can deduce after the research in this article that as an independent and irreplaceable structure, the small and medium enterprise sector in Moldova constitutes one of the most efficient levers that contribute at solutioning the economic and social problems. It also is a factor which structurally transforms the economy, consolidates its economic base and its zones, fulfils in an accelerate mode the market with goods and services, attenuates the monopolism and favours competition development, implementation of scientific and technical achievements, the country's increasing export opportunities, , providing new jobs to a large number of people.
\end{abstract}

\section{Keywords}

Small business, entrepreneur, competition, financing opportunities, commercial credit, venture type financing, leasing, franchising, financial mechanism.

JEL Code: G32

\section{The Evolution of Small Businesses}

An indespensible condition of Moldovan economy revival in market relations becomes the development of entrepreneurial activity - particularly of that special style, innovative, antibirocratic oriented towards new business development search, towards innovation in order to accelerate economic development and achieve maximum profit.

In any business any beginning is doomed to failure unless it is driven by a substantive financial contribution. And if the new start is going bad, or rather it does not go at all, we can conclude that there are very few of those who can get this foundation, the credit. Banks survive and thrive out of these loans, but, unfortunately, higher interest rates and the conditions imposed by banks (mortgage should exceed the loan, the lack of holiday repayment, very appropriate for a beginner) all these mentioned above are credited impossible for the most "new infants" of business.

In our country the problem is amplified by the fact that banking institutions are still weak and can not afford to give anyone credit. Money is readily available for those who already have a business and have benefited from loans from the bank, as they have a credit history. But what about others? Others need guarantees. And these could come either from other economic agents or from the state.

The private business in the Republic of Moldova has started to unfold and develop in the late 80 s, after Gorbachev's liberalization. The first signs of private companies started to appear with the first cooperative fondations.

The latter have disappeared with time; instead there appeared Ltds, joint stock companies and individual enterprises. 
After privatization started off there appeared Farmers' Associations Farmers' Households, etc.

The purpose of all those who have started their own business has been to gain own money in a business. And from here the problems commenced. The first problems are linked to the mentality. The new phenomenon of private business was very hard to assimilate. Usually such people were regarded with suspicion as people who demolish the society system.But this state of doubt was resolved fairly quickly, and the business started to prosper and with the pioneers in the field, and then the others who wanted to have their own business took the idea.

These first problems would seem quite easy for the businessmen who later on encountered more difficult problems. The latter problems would last until our days - relationship with the State and any other state institututions.

The State suddenly began to take interest in most of private business activity. This happened after a long time of unnoticing it. There appeared a new pathology at the organs of state - a chronic fear not to let people get rich. And the State began to create obstacles. There emerged higher taxes, frequent controls, excessive hygienic requirements, standards, licensing, permits, etc.

For some large enterprises such things were known, or at least easy to fit into them, taking into account their financial strength.

Meanwhile, small business offers real opportunities to implement creative entrepreneur skills, also the inventiveness and leadership - quite necessary and useful qualities in life. Small business in Moldova, as in most developing countries, has emerged as a result of structural reforms undertaken in the transition from centralized to market economy.According to BIZPRO Moldova Project today, almost 90 percent of the country's businesses are small business enterprises, of which 73 percent are micro enterprises and 19 percent are small businesses.

Currently, small business structure roughly reflects the situation of 2000: there is now predominant commercial activity - 45 percent, followed by manufacturing of agricultural raw materials and mining - 13 percent, property transactions - 11.8 percent, transport and telecommunications - 6.5 percent, construction - 5.7 percent. A developed economy is nothing else but healthy companies, business oriented towards a continuous development, with new technology implementation, and what is most important with a consumer with high purchasing power. Something hints to the idea that none of these elements are present, which leads to the bankrupt economy we live in. Consumers thus are nothing but a middle class, which is represented in developed countries by private entrepreneurs, people who own small and medium business.

If you have a good idea for business, the qualities, strength and energy necessary to achieve it, but you do not have money, it gives you no reason to stop and wait, once they appear. You should give evidence of persistence, insistence, courage to seek, where you really get money necessary for the realization of your plans. In this article we are going to list various methods of raising funds in Moldova, to open and manage your business.

\section{Funding Sources}

So, there are several sources of funding such as:

1) Partner Search

While organizing your company, start looking for a partner who, in your opinion, could fit the role of financial investor. Usually, it happens so: you have the idea, and someone else has the money. Or vice versa. If you have a good idea, be careful that your idea does not pass to someone else. Do the same if you own money.

2) Financing venture

If you are planning to start a business related to the development and production of knowledge-intensive products, look for long-term investments (5-7 years) of private equity 
in your capital, which scientifically is called venture funding. In Moldova this type is not yet developed, but it can attract outside capital.

3) Commercial loan (of goods)

Commercial loan can be defined as a form of merchandise credit, provided by sellers to buyers with a postponement of payment for goods sold. In other words, if you do not have money to pay for goods, you can get credit.

4) Leasing

It submits a loan for equipment, with the right of redemption or without it. In Moldova there are about 8 leasing companies, of which we should later speak. You can take the machine or equipment necessary to carry out operation in leasing business (if you receive it), spending saved money on promotion or services.

5) Franchising

Franchising is an agreement between business systems through which one party - franchiser shall exchange - franchise - gives the right to produce and / or market a particular product type (goods), providing services on behalf of and with the franchiser's trademark and having the right to receive technical and organizational support.

Franchising can be an indirect source (when saving to everything that ought to be acquired after years) or directly (when the franchiser's financially supports you until you set sure) to finance your business.

6) Grants and philanthropic contributions

The grants are means, provided free by the donor (a fund, a corporation, a government institution or an individual) to a non-commercial organizations or individuals carrying out a specific activity. Unlike the loan, grants are not to be returned.

To obtain a grant, it is necessary to prepare a project in which to specify how, why, and with whom you want to do that activity. Usually, grants are offered for a social project office, but in Moldova they are offered to support small business too. Thus, there is a chance, but remember that competition for philanthropic funding sources worldwide is very acute. It would be unfortunate to submit some work for nothing. A grant application requires a very thorough preparation.

7) Barter

One of my acquaintances successfully used barter transactions at the beginning of his business. Make a list of those what you would need in business management (besides money), take a directory of businesses and make telephone calls to all companies that sell goods and services you need, offering them a deal barter. The result will exceed all your expectations.

8) Loan

The loan means to lend goods or money, usually by paying interest. The loan is the source of funds most widespread in Moldova. It is given both by banks and non-bank credit institutions.

If you need a moderate amount (up to 30,000 lei), then it is better to take credit on an individual. The process of preparing all the necessary documents will occupy several days.

Also, you can always borrow money from relatives or friends, but you should think about whether such financial relationships will not ruin your friendships.

Of course, each funding source must be examined in more detail.

In Moldova, the loans will be redirectioned by 2-4 operators through commercial banks.It is the case to mention that MoSEFF program is not just a line of credit. Companies in the program receive assistance in optimizing decisions in the energy sector. Besides financing, the EBRD has invited a group of local and international experts led by German company "Fichtner", which will help potential benefeciari to choose optimal decisions under investment requirements and most appropriate technical and financial decisions. Also, experts will help the clients prepare longstanding demand for participation in the grant program. Expert's group work is funded by the European Commission, so technical assistance for potential beneficiaries will be free of change. The group is formed of 6 local 
and 6 international experts who will work at the enterprise depending on project complexity from 2 to 5 days.

Credits will be granted for a term of 5-10 years with an interest rate market conditions. Loans for projects successfully implemented will have a grant component ranging from 5-20 percent. Thus, for effective implementation of projects financed by $25-150$ thousand euros, the grant will be 10 percent of the loan amount when applying traditional technologies and 20 percent for use of innovative technologies. In projects funded with amounts of between 150 thousand and 2 million are the same criteria. Grant amounts for major projects in renewable energy production will be 15 percent.

EBRD representatives points out that sometimes the simplest solutions save significant amounts of energy. A simple solution, for example, is the insulation of buildings. Such measures are eligible for the project as the application of modern technologies.

It looks a little strange to talk about business or about initiation of some business ideas while the global economic crisis arrived in Moldova, but things are not so negative. Life does not end at crisis arrival; it simply passes more or less at a lower level. Same happens with money: they leave expensive goods and services market in favor of cheaper products.

Thus, those who could afford more before the crisis, now they have to save, to move from goods and services which are less necessary to those essentials and cheaper.

Of course, this is not the time to start a business selling yachts, even if Moldova has sea ports. It is alsi not any estate business while the construction stalled. In such a case a wayout should be found, a wayout which would resist even the financial situation of our country and will benefit from crisis in Moldova. Sounds incredible? But not impossible!

Collection agency - is the civilized name of debt repayment process of those who do not pay. With the crisis the number of those who do not wish to pay debts increases: the first group can't because of crisis objective reasons, the others only are pretending the reason is crisis.

Agencies do not collect primitively anymore, they thrust on law. This kind of activity in Moldova is quite new and is practiced by lawyers in particular. There are several types of collectors. Some work only with banks, especially concerning themselves with ustomers who don't pay. The others are involved insolving the financiary problems among various companies. There are also collectors who work with individuals. Time to mention that in Moldova there are already several offices of lawyers who deal professionally with debt repayment.

Alternative energy sources and other ways to save

When spending exceeds income more people begin to think how they could save and this is already noticed in Moldova.

A successful business could become sale or rental of solar batteries for power generation.Moldova is a country with most of the sunny season and is therefore we shouldn't ignore this advantage.

Taking into account that alternative energy sources are still quite expensive, they can be sold or leased rate. So your bid will benefit more customers.

It deserve attention, especially in times of crisis, all that saves water, natural gas, gas, electricity.

Sales assistance.

In times of crisis many things (the second or third TV, luxury car, etc.) lose their timeliness and their owners try in every possible way to sell them. But this is not an easy thing to do, especially it needs time, and during crisis time it is much harder to sell something.

The idea is that business is to look for professional buyers through the Internet, media or markets, with a certain percentage of sales.

Tourist Agency accesible.

Even during crisis Moldovans will not abandon the rest, especially if they will have no job. Simply there will be less money for rest. 
Business idea is to open an accesible travel agency. As travel destinations could serve both localities in the country and neighboring countries - Ukraine, Romania.

Lombard or microfinance services.

When the banks and lending institutions that grant credit to people cease such activity it is appropriate to open a Lombard or initiate an activity of microfinancing private persons.

Psychological assistance.

If you are a psychologist or have acquaintances that could start a business, examine the possibility to provide psychological care to businessmen or other wealthy people, who have suffered from the crisis.

Natural household.

Even in times of crisis people want to eat. Probably the least affected by the crisis will be rural residents and owners of gardens and domestic animals. Under these conditions the idea of an agricultural business deserves attention, obviously, if you desire and possess those capabilities. The crisis will not last forever. After the crisis there will necessarily be an increase. Those who resist now will now have greater opportunities in future. Even if your idea does not mean income right in the time of crisis, go slowly and surely toward the goal, and after the crisis you are to be one of the first in the field you have chosen.

Personnel redundancy - convenient modality.

At first, everything seems simple - you invite the person concerned in the office and notify him of the decision and problem is solved. But things are more complicated, because the legislation requires that the employer to comply with a set of rules and obligations to the employee.Moreover, compliance with those rules can create unwanted problems to company.

There are several ways to correct dismissal of staff:

1. Friendly disposal. In this case the company agreed with the employee on material compensation, preparing the necessary documents and all parties are satisfied. This approach is most effective and simple when redundancy is inevitable, but is rarely encountered.

2. Dismissal based on their requests. Obviously, the company considers this method the most convenient in terms of money, because it may not pay any compensation, but in this case it is likely to consider further the employee unlawfully dismissed. In this case judicial debate and labor inspection controls are inevitable. It is very important that you do not have any debts to the employee (overtime pay, unused leave, etc.). Much easier it is to pay the employee wholly to avoid unwanted problems in the future.

3. Dismissal for breach of labor discipline, of course, if there exist premises. This can occur when such serious violations, as come drank in the office, breach of the work, systematic delays, and absences without leave. But if the deviations were not quite so seriousit is most likely thet if going to the court occurs, the employer will be right.

Where redundancy of good specialists is undesirable, the best solution would be to reduce schedule worktime and give leave for a long term. These measures will help keep qualified personel for better times, but in this case the risk is that these specialists would find another job.

In order that the crisis measures do not affect the company follow some expert advice:

If you intend to fire some employees, it's good to redundant a few people at once, so that other employees should not in a situation of stress and thinking about who will be next on the list. After the procedure has take place, you should call all employees and explain the reasons for their dismissal. Also, the staff must be initiated in the company's future plans and to undertake additional measures for reasons of remaining employees.

However, as far as possible there should be taken care of redundant employees. Explain that they were fired not because of their fault, but due to adverse circumstances affecting the company. Provide a written recommendation and give them all possible assistance.

And remember - to avoid unwanted situations in the dismissal of staff studiy the Labor Code of the Republic of Moldova, cause the person informed is the person protected. 


\section{Bibliography}

1) Legea RM cu privire la susținerea şi protecția micului business din nr.112-XIII din 20 mai 1994

2) Hotărîrea Guvernului RM nr.750 din 5 august 1999 cu privire la Programul de Stat de susținere a micului business pentru anii 1999-2000

3) Graur E., (2005) Cadrul legislativ-factor de incurajare a antreprenorilor la demararea micilor afaceri // Revista economică, nr. 3(22), Sibiu - Chişinău, p. 74-80.

4) Doga V., Rusu S., Graur, E. (2005) Aspecte in relansarea micului business din RM in contextul integrării europene // „Perspective ale restructurării şi relansării agriculturii in competiția pentru integrarea in Uniunea Europeană”, Simpozion ştiințific internațional, 2005, p. 22-26.

5) Erhan V. (2003) Corelația dintre sistemul bancar şi micul business in R.Moldova /V.Erhan//Economie şi sociologie. - Chişinău: Editura ASEM, nr.3. - p.70-79.

6) Erhan V. Dinamica microfinanțării in economia națională /V.Erhan// Economie şi sociologie. Chişinău: Editura IEFS, 2008. - nr.3. -p.111-122. 